\title{
Tentacle cnidae of the sea anemone Metridium senile (Linnaeus, 1761) (Cnidaria: Anthozoa)
}

\author{
CARINA ÖSTMAN ${ }^{1}$, JENS ROAT KULTIMA ${ }^{2}$ and CARSTEN ROAT ${ }^{3}$ \\ ${ }^{1}$ Animal development and Genetics, Evolutionary Biology Centre (EBC), Uppsala University, Norbyvägen 18A, \\ SE- 75236 Uppsala, Sweden. E-mail: Carina.Ostman@ebc.uu.se \\ ${ }^{2}$ Uppsala University, Norbyvägen 18A, SE-752 36 Uppsala, Sweden. \\ ${ }^{3}$ Department of Ecology, Environment and Geology, Umeå University, Linneus väg 6, SE- 90187 Umeå, Sweden.
}

\begin{abstract}
SUMMARY: Tentacle cnidae of Metridium senile (Linnaeus, 1761) were examined by light microscopy. In addition to spirocysts, feeding-tentacles had 3 nematocyst categories grouped into medium and small size-classes, including 5 types. Spirocysts dominated, especially distally, followed by medium b-mastigophores. The density of cnidae decreased towards the tentacle base. Early cnidoblasts were numerous on the tentacle tip. Late cnidoblasts appeared in a moderate number on the mid-tentacle. Catch-tentacles, found in two Metridium specimens, had a maturity gradient of isorhizas and gland cells along their length. Their tip had two distinct types of mature isorhizas in great numbers and large gland cells, but lacked spirocysts. Mature isorhizas and gland cells decreased in number towards the tentacle base. On the mid-tentacle differentiating ages of isorhizas were numerous. Ordinary feeding-tentacle cnidae, abundant at the tentacle base, decreased in number distally along the tentacle.
\end{abstract}

Keywords: sea anemone, nematocysts, cnidae, catch-tentacles.

RESUMEN: Cnidoma de los tentáculos de la anémona de mar Metridium SENILE (Linnaeus, 1761) (CNidaria: AnTHOZOA). - El cnidoma de los tentáculos de Metridium senile (Linnaeus, 1761) se examinó mediante microscopio óptico. Además de espirocistos, los tentáculos tenían 3 categorías de nematocistos agrupados en clases de talla medianas y pequeñas, incluyendo 5 tipos. Los espirocistos fueron dominantes, en particular distalmente, seguidos por b-mastigióforos medios. La densidad de cnidoma decreció hacia la base del tentáculo. En la punta del tentáculo fueron abundantes los cnidoblastos jóvenes. Los cnidoblastos avanzados aparecieron en número moderado a mitad del tentáculo. Los tentáculos hallados en dos especímenes de Metridium presentaron un gradiente de madurez de isorhizas y células glandulares a lo largo de su longitud. La punta tenía dos tipos distintos de isorhizas maduras en gran número y grandes células glandulares, pero les faltaban espirocistos. Las isorhizas maduras y las células glandulares disminuyeron en número hacia la base del tentáculo. A mitad del tentáculo, se observaron numerosas isorhizas de diferentes edades. Los cnidocistos de los tentáculos, abundantes en la base del tentáculo, disminuyeron en número distalmente a lo largo del tentáculo.

Palabras clave: anémona de mar, nematocistos, cnidoma, tentáculos.

\section{INTRODUCTION}

Metridium senile (Linnaeus, 1761) is a passive suspension-feeder (Purcell, 1977a). Short translucent feeding tentacles, tapering gently from base to tip, occur in cycles and form a tentacle crown around the mouth (Batham and Pantin, 1951). The tentacles, equipped with numerous cnidae, capture zooplankton and pass them to the mouth (Koehl, 1976; Purcell, 1977a; Sebens, 1981). The size of zooplankton, which an anemone can capture, does not increase with the anemone size (Purcell, 1977a; Sebens, 1981; Sebens and Koehl, 1984; Kramer and Francis, 2004). However, the surface area of the tentacle crown increases proportionally with the body size (Sebens, 1981). Tentacles of determinate length are added to the tentacle crown as the anemone grows (Sebens, 1979).

Certain anemones possess a second tentacle type known as a catch-tentacle (Williams, 1975) or, more appropriately, a fighting tentacle (Purcell, 1977b; Pur- 
cell and Kitting, 1982). These tentacles are not used for catching prey, but are specialised for aggression between clones (Williams, 1975, 1980, 1991; Purcell, 1977b; Watson and Mariscal, 1983a,b; Bigger, 1988). Appearing in the innermost circle of the tentacle crown, they are opaque with a blunt tip and twice as thick as a feeding-tentacle (Williams, 1975).

Catch-tentacles are not found in all individuals, their development being stimulated by territorial threats from non-clonemates. Feeding-tentacles can transform into catch-tentacles when the anemone's territory is threatened. Their developments have been induced after non-clonemate individuals are placed together in crowded anemone cultures (Purcell, 1977b; Watson and Mariscal, 1983b). Following contact with a non-clonemate, a cascade of hostile acts commences (Purcell, 1977b). Catch-tentacles become inflated up to four times their resting length; they adhere onto their rival and discharge nematocysts. As the catch-tentacle is withdrawn, its tip might autotomise.

Aggression is important in competition for space. Narrow corridors free of anemones often separate clones of different species or different clones, and individuals bearing catch-tentacles are found predominantly along these borders (Purcell, 1977b; Purcell and Kitting, 1982; Fukui, 1986). Catch-tentacles have been recorded in $M$. senile from the British coast (Williams, 1975) and from the Netherlands coast (Ates, 1989) and in the Californian M. farcimen (Brant, 1835) (Hand, 1956, 1961; Purcell, 1977b). They have not previously been described in Scandinavian M. senile (L).

Differences in cnidae between feeding-tentacles and catch-tentacles are reported in several anemones: in Diadumene (Carlgren, 1929 ("Fangtentakeln")), in Metridium (Hand, 1956; Williams, 1975; Purcell, 1977b; Kaplan, 1983) and in Haliplanella luciae (Watson and Mariscal 1983a,b, 1984a,b; Fukui, 1986). With the exception of spirocysts, all cnidae found in the ordinary tentacles are found in the catch-tentacle but in less abundance (Williams, 1975, Purcell, 1977b). Spirocysts that often predominate in feeding-tentacles are rare or absent in catch-tentacles (Williams, 1975; Purcell, 1977b). Catch-tentacles are dominated by atrichs and/or holotrichs, which are considered to be related to aggressive behaviour (Williams, 1975; Purcell, 1977b; Watson and Mariscal, 1983a,b; Fukui, 1986). The atrichs and holotrichs recorded by the authors mentioned above are here referred to as subtypes of isorhizas (see Östman, 2000), according to the nematocyst nomenclature proposed by Mariscal (1974) and Calder (1977).

Watson and Mariscal (1983b) described the differences in distribution of mature and developing cnidae in the feeding- and catch-tentacles of $H$. luciae. They reported mature cnidae along the feeding-tentacles on the epithelial surface, and cnidoblasts below along the nerve plexus. A similar distribution of cnidoblasts was reported by Westfall (1966) in $M$. senile. The catch-tentacles had a maturity gradient of cnidae and gland cells along their length with mature holotrichs and a large gland cell concentrated at the tentacle tip (Watson and Mariscal, 1983a,b). Their TEM observations (1983b) revealed two holotrichous isorhizas: small holotrichs distributed along the epidermal surface and large holotrichs recessed beneath the small holotrichs, but still in the epidermis (p. 941, Fig. 1).

Based on the maturity gradient of holotrichs and gland cells, Watson and Mariscal (1983b) divided the catch-tentacle into four regions: the catch-tentacle tip filled with mature, small and large holotrichs and numerous large gland cells; the upper-middle catchtentacle, in which all holotrichs present were not mature and the gland cell had few granule vesicles; the lower-middle catch-tentacle, with few mature holotrichs and numerous cnidoblasts involved in external tubule formation or tubule internalisation into the capsule, and with small and rare gland cells; and the catch-tentacle base, with numerous early-age cnidoblasts involved in capsule or external tubule formation. Mature holotrichs were absent, and gland cells poorly developed. Common feeding-tentacle cnidae were abundant at the tentacle base, their number decreasing distally along the tentacle. Spirocysts were not present at the tentacle tip

Fukui (1986) reported, in the catch-tentacles of $H$. luciae, numerous large atrichs (corresponding to large holotrichs of Watson and Mariscal, 1983b) and holotrichs (corresponding to small holotrichs of Watson and Mariscal, 1983b) accompanied by some other types of cnidae.

The present report describes and illustrates the size, abundance and maturation of feeding-tentacle cnidae of M. senile. Also described is the differentiation of shafts if present. Comparisons are made with descriptions of nematocysts from acontia (Östman et al., 2010a). We also report the size and abundance of nematocysts from column and oral discs (Table 1). Two specimens of $M$. senile from the Swedish west coast were found with catch-tentacles equipped with isorhizas (here referred to as catch-tentacle isorhizas). Preliminary observations on their distribution and maturation are presented. Our findings are compared with those of Hand (1956), Watson and Mariscal (1983b) and Kramer and Francis (2004).

\section{MATERIALS AND METHODS}

Metridium senile were collected from the Gullmarsfjord on the Swedish west coast $\left(58^{\circ} 15^{\prime} \mathrm{N}, 11^{\circ} 28^{\prime} \mathrm{E}\right)$ in June-August 1996-2003. Small M. senile (pedal disc diameter (PPD) $<20 \mathrm{~mm}$ ) were found in mass aggregations in the immediate sub-surface region and down to $2 \mathrm{~m}$. Large solitary individuals (PPD up to $45 \mathrm{~mm}$ ) were commonly found down to $20 \mathrm{~m}$. All samples were taken from hard substrates. Cnidae were investigated from specimens of different sizes.

Catch-tentacles were only found in two large solitary $M$. senile during 6 years of study. One grew in 
TABLE 1. - Size in $\mu \mathrm{m}$ and abundance of undischarged cnidae from tentacles, columns and oral discs of Metridium senile (L.) from Sweden and of M. farcimen (as M. s fimbriatum) from California (Hand, 1956)

\begin{tabular}{|c|c|c|c|c|}
\hline $\begin{array}{l}\text { Cnidae fom tentacle, column plus oral disc } \\
\text { and minimum samples of structure } \\
\text { investigated }\end{array}$ & Abundance (1) & No & $\begin{array}{c}\text { Range } \\
\text { Length (mean) x width (mean) }\end{array}$ & $\begin{array}{c}\text { Range } \\
\text { Length / width }\end{array}$ \\
\hline \multicolumn{5}{|l|}{ Metridium senile (L.), Sweden } \\
\hline \multicolumn{5}{|l|}{ Feeding-tentacle $(N=17)$} \\
\hline microbasic b-mastigophores, small & ++ & 139 & $9.0-22.0(13.4) \times 2.0-2.5(2.1)$ & $4.0-11.0$ \\
\hline microbasic b-mastigophores, medium & ++++ & 357 & $13.0-33.0(20.5) \times 2.5-4.0(3.0)$ & $4.3-9.7$ \\
\hline microbasic p-amastigophores, small & rare or + & 57 & $10.0-15.0(13.2) \times 3.0-4.5(3.8)$ & $2.5-5.0$ \\
\hline microbasic p-amastigophores, medium & +++ & 256 & $15.0-30.0(21.4) \times 3.0-5.0(4.0)$ & $3.0-8.6$ \\
\hline isorhizas, small - medium (ordinary) & + & 121 & $13.0-29.0(19.2) \times 2.5-6.0(3.9)$ & $2.9-6.6$ \\
\hline spirocysts, small - medium & +++++ & 100 & $10.5-30.0(19.7) \times 2.5-5.0(4.0)$ & $3.1-7.7$ \\
\hline \multicolumn{5}{|l|}{ Catch-tentacle $(\mathbf{N}=2)$} \\
\hline microbasic b-mastigophores, small & + & 25 & $9.0-13.0(11.6) \times 1.5-2.5(2.1)$ & $4.4-6.7$ \\
\hline microbasic b-mastigophores, medium & + & 12 & $18.0-26.0(21.9) \times 3.0-3.5(3.1)$ & $5.7-8.7$ \\
\hline microbasic p-amastigophores, small & + & 14 & $10.0-16.0(14.0) \times 3.0-5.0(4.2)$ & $2.2-5.0$ \\
\hline microbasic p-amastigophores, medium & + & 55 & $17.5-37.5(26.1) \times 4.0-6.0(4.6)$ & $3.5-8.3$ \\
\hline isorhizas, small - medium (ordinary) & rare & 13 & $15.0-20.0(18.0) \times 4.0-5.0(4.7)$ & $3.0-5.0$ \\
\hline catch tentacle isorhizas, small & +++++ & 41 & $14.5-20.0(16.9) \times 3.5-5.5(4.5)$ & $3.0-5.3$ \\
\hline catch tentacle isorhizas, large & ++++ & 42 & $25.5-38.5(31.8) \times 8.0-12.5(10.7)$ & $2.2-4.3$ \\
\hline spirocysts, small - medium & rare or + & 22 & $14.0-30.0(18.8) \times 3.0-5.0(3.5)$ & $4.0-7.5$ \\
\hline \multicolumn{5}{|l|}{ Column plus oral disc $(N=6)$} \\
\hline microbasic b-mastigophores, small & + & 60 & $8.0-14.5(11.1) \times 2.0-2.5(2.1)$ & $4.0-7.3$ \\
\hline microbasic b-mastigophores, medium & +++ & 131 & $12.5-30.0(15) \times 2.5-.4.0(2.9)$ & $4.0-10.0$ \\
\hline microbasic p-amastigophores, small & rare & 26 & $8.0-13.5(11.6) \times 3,5-4.0(4.0)$ & $2.3-3.4$ \\
\hline microbasic p-amastigophores, medium & ++ & 138 & $15.0-30.0(21.0) \times 3.0-6.0(4.3)$ & $3.6-7.5$ \\
\hline isorhizas, small - medium (ordinary) & rare to + & 21 & $12.0-20.0(15.4) \times 4.5-5.5(4.9)$ & $2.4-4.4$ \\
\hline \multicolumn{5}{|c|}{ Metridium farcimen (as Metridium senile fimbriatum), California (Hand, 1956) } \\
\hline \multicolumn{5}{|l|}{ Tentacle } \\
\hline basitrichs (= b-mastigophores, small) & & 63 & $6.0-15 \times 1,5$ & \\
\hline microbasic b-mastigophores (= b-mastigo & s, medium) & 78 & $12.0-32 \times 2.0-3.5$ & \\
\hline microbasic amastigophores $(=\mathrm{p}$-amastigo & es, medium) & 85 & $20.0-37.5 \times 4.0-6.0$ & \\
\hline spirocysts & & 50 & $12.0-30.0 \times 4.0$ & \\
\hline \multicolumn{5}{|l|}{ Catch-tentacle } \\
\hline \multirow{2}{*}{\multicolumn{2}{|c|}{ microbasic amastigophores (p-amstigophores, medium) }} & 70 & $20.0-35.0 \times 4.0-5.0$ & \\
\hline & holotrichs (= catch-tentacle isorhizas, small) & 89 & $13.5-23.0 \times 4.0-6.0$ & \\
\hline \multicolumn{2}{|l|}{ atrichs (= catch-tentacle isorhizas, large) } & 91 & $24.0-47.5 \times 7.0-15.0$ & \\
\hline
\end{tabular}

$\mathrm{N}$, number of samples, each taken from a different anemone; 1 , abundance of cnidae: +present, +++++ very abundant;

absent to rare, cnidocysts not always found in the structure examined.

shallow water at a depth of $0.25 \mathrm{~m}$. The other was found in the exhibition aquarium of the Klubban Biological Station in the Gullmarsfjord.

Methods of preparation for light microscopy, light microscopes with ancillary equipment, nematocyst identification and terminology, cnida measurements and abundance calculations are as described by Östman (1987) and Östman et al. (2010a). Measurements and abundance of cnidae are given in Table 1. Size comparisons are made on the length of undischarged nematocysts from anemones of different sizes, and the data are analysed with regression tests.

\section{RESULTS}

\section{Cnidae studied}

Feeding-tentacle cnidae and their development are described and illustrated (Figs. 1, 2). Catch-tentacle isorhizas are illustrated in Figure 3 and their development in Figure 4. Cnidae, including nematocysts and spirocysts, are classified and characterised as follows;
1. Microbasic b-mastigophores, small and medium, capsule narrow elongate; from tentacle (Fig. 1a,c,e, Table 1), column and oral disc. Small and medium microbasic b-mastigophores corresponding to basitrichs and microbasic b-mastigophores (Carlgren, 1945; Hand, 1956; Westfall, 1965, 1966; Purcell, 1977b; Watson and Mariscal, 1983a,b; Kramer and Francis, 2004). Inverted shaft a distinct thin rod. Distal tubule in regular, slightly oblique, dense coils, perpendicular to long capsule axis. Discharged shaft microbasic, about one capsule length (Fig. 1f).

2. Micro- and mesobasic p-amastigophores, small and medium, capsule elongate; from tentacles (Fig. 1a,c-e, Table 1), column and oral disc, corresponding to microbasic amastigophores (Carlgren, 1945; Kramer and Francis, 2004) and to microbasic p-mastigophores (Watson and Mariscal, 1983a,b). Inverted shaft rodshaped, border between proximal shaft and main shaft distinct; V-shaped notch at distal end of main shaft. Tiny, distal tubule from V-notch. Internal capsular matrix U-shaped to irregular. 

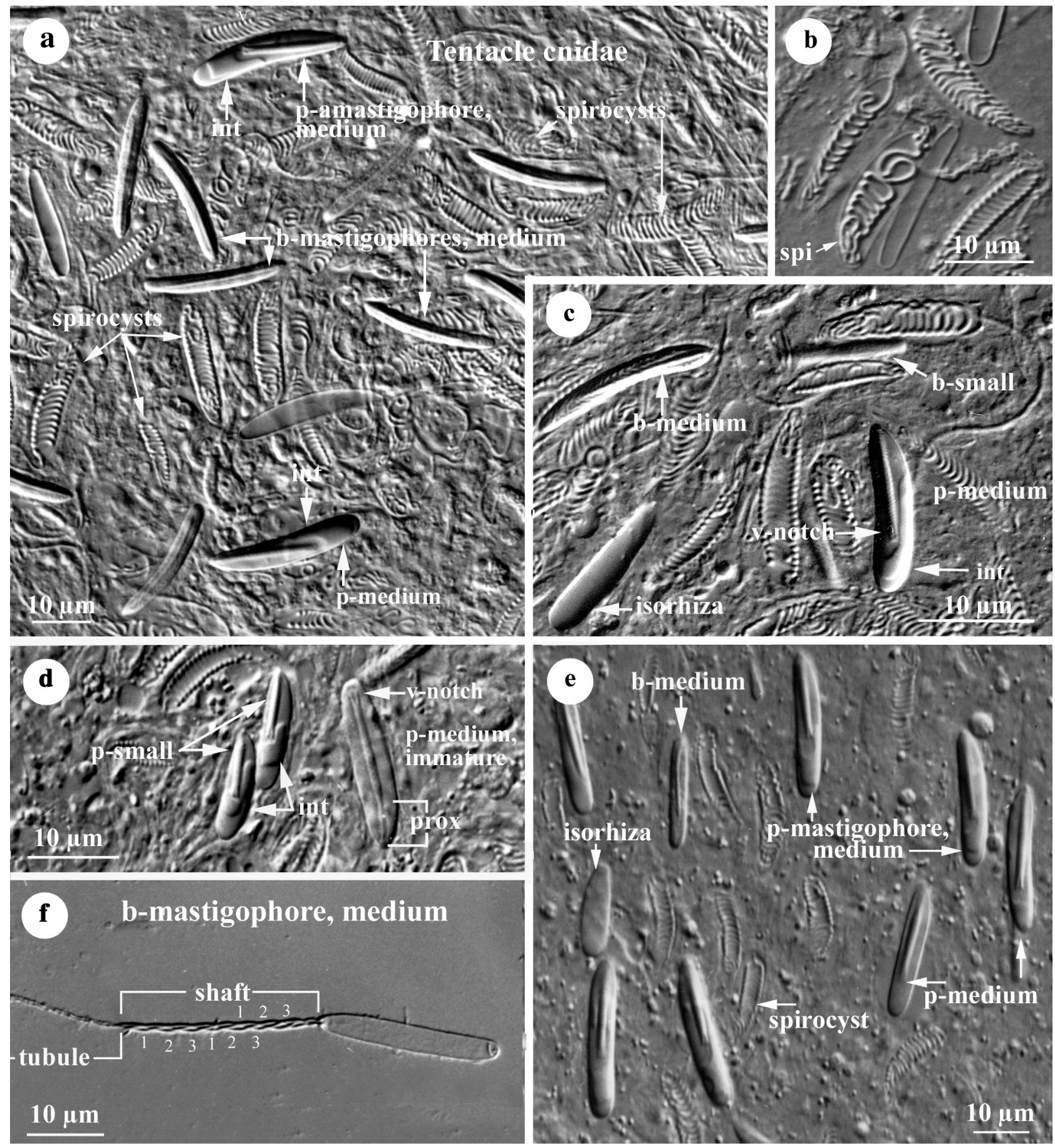

FIG. 1. - Feeding-tentacle cnidae. a) Distal tentacle; spirocysts dominate followed by b-mastigophores, medium. Note part of asymmetric, rounded U-shaped capsular matrix in p-amastigophores, medium. b) Undischarged and partly discharged spirocysts. c) Upper mid-tentacle showing spirocysts, b-mastigophores and p-amastigophores, small and medium, and one isorhiza. d) Mid-tentacle: p-amastigophores, small, with square $U$-shaped capsular matrix close to base of inverted shaft; one immature p-amastigophore, medium, with narrow structure in proximal shaft (prox) and V-shaped notch at end of main shaft close to capsule base. e) Tentacle base: cnidae oriented along long axis of tentacle, p-amastigophores, medium dominate. f) Discharged b-mastigophore, medium. Note microbasic shaft with helical spine-rows and distal tubule with tiny spines. $b$-medium, b-mastigophore, medium; $b$-small, b-mastigophore, small; int, internal capsular matrix; $p$-medium, p-amastigophore, medium; prox, proximal; -small, p-amastigophore, small; $v$, $v$-notch, V-shaped notch at shaft end; 1, 2, 3, three spine-rows.

3. Isorhizas, small to medium, capsule broad, elongate; from feeding-tentacles (Fig. 1c,e, Table 1), column and oral disc. Irregular loose coils of tubule not filling entire capsule (Fig. 2f).
4. Spirocysts, small to medium; capsule broad, elongate, slightly bow-shaped; restricted to tentacles (Fig. 1a-e, Table 1). Tubule in dense regular coils, perpendicular to long capsule axis, filling capsule. 

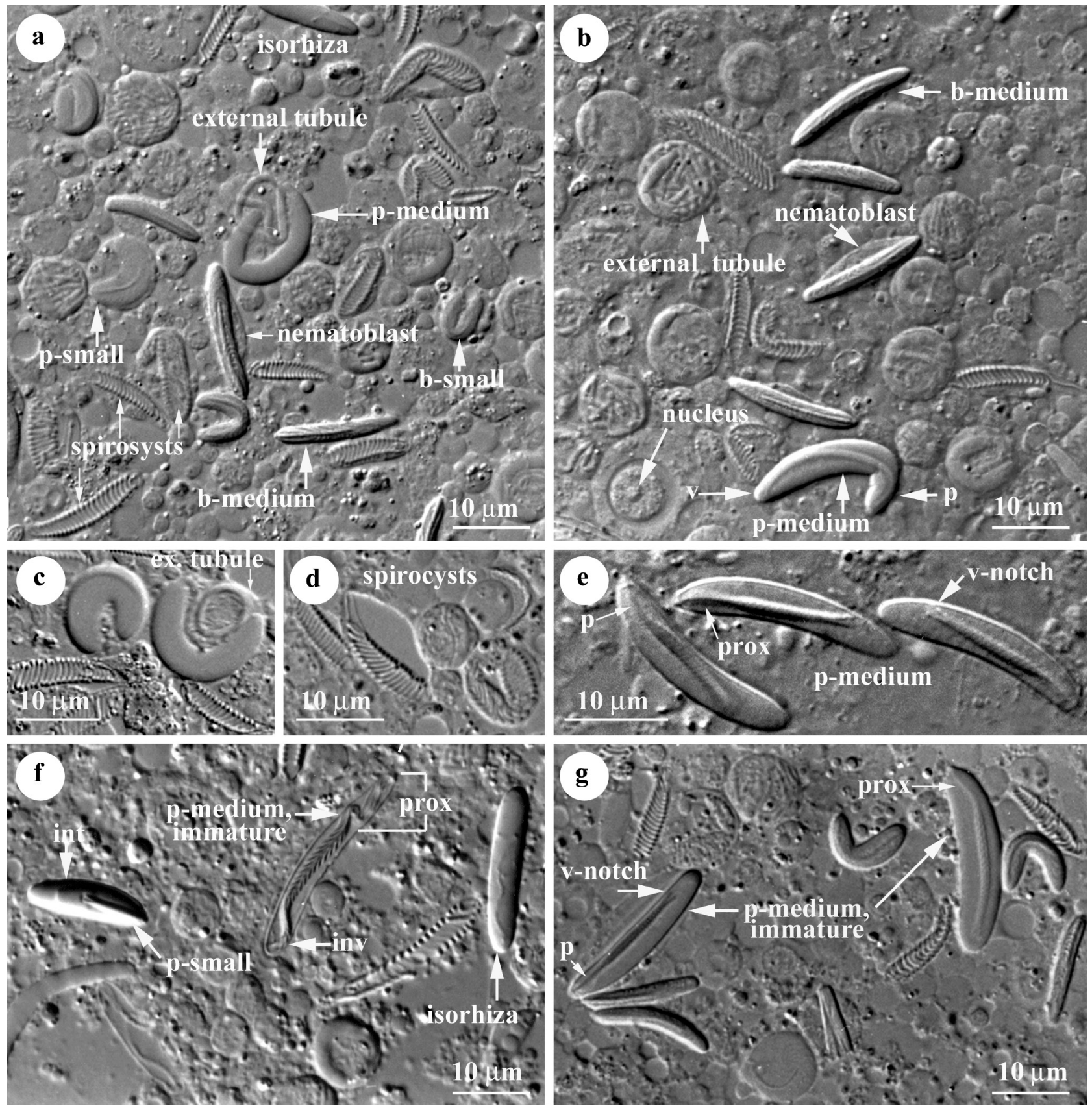

FIG. 2. - Feeding-tentacle cnidae, mature and maturing, from proliferation zones. a,b) Large numbers of round cnidoblasts early in development with amorphous capsular contents, and cnidoblasts with folded capsule and external or internal tubule. a) Note external tubule in connection with broad, folded capsule; the nematoblast is missing. b) Note one round cnidoblast with amorphous cell contents and large nucleus (lower left corner). Note nematoblast in connection to one b-mastigophore, medium, and one partly folded p-amastigophore, medium, with V-notch close to capsule base (v). c) Folded p-amastigophore capsules, medium; one with external tubule and one with partly developed shaft inside. d) Spirocyst inside cnidoblast. Note folded capsule. e) p-amastigophores, medium, late in development. Note faintly visible thin structure on proximal shaft (p, prox), helical pattern on main shaft and V-notch at its end. f) One developing p-amastigophore, medium, with flexed proximal shaft (prox) and V-shaped spine pattern along main shaft; distal shaft (inv) will later invert and form the V-shaped notch. Note one p-amastigophore, small, with capsular matrix, and one isorhiza with short tubule. g) Note immature p-amastigophore, medium with narrow structure on proximal inverted shaft (p, prox), and probably $2 \mathrm{~b}$-mastigophores, small, bow-formed. $b$-medium, b-mastigophore, medium; $b$ small, b-mastigophore, small; ex., external; int, internal capsular matrix; inv, basal shaft, which later will invert; $p$-medium, p-amastigophore, medium; p, prox, proximal shaft, p-small, p-amastigophore, small; $v$, v-notch, V-shaped notch at end of shaft.

5. Catch-tentacle isorhizas, small; capsule elongate; solely in catch-tentacles (Fig. 3b,d, Table 1). Corresponding to holotrichs (Hand, 1956; Purcell, 1977b; Fukui, 1986) and to small holotrichous isorhizas
(Watson and Mariscal, 1983b). Tubule in loose regular coils perpendicular to long capsule axis, not filling entire capsule (Fig. 3g).

6. Catch-tentacle isorhizas, large, capsule broad, 
ovate, solely in catch-tentacles (Fig. 3c, Table 1). Corresponding to atrichs (Hand, 1956; Purcell, 1977b), to large atrichs (Fukui, 1986) and to large holotrichous isorhizas (Watson and Mariscal, 1983b). Tubule in dense irregular coils perpendicular to main capsule axis, filling entire capsule.

\section{Feeding-tentacles and their cnidae}

The filiform feeding-tentacles (Fig. 3a) were translucent, slightly greyish and tapered gently from base to pointed white tip. Their cnidae (Fig. 1) were dense and transversely arranged in the ectoderm of distal and main tentacles. Towards the tentacle base cnidae were scarce. Close to or at the tentacle base, cnidae were often aligned along the tentacle axis (Fig. 1e).

Spirocysts were most abundant (Fig. 1a-c, Table 1) and outnumbered all the other tentacle nematocysts combined. At the tentacle tip spirocysts clearly dominated, but decreased in number towards the midtentacle region, and more so near the base. Medium b-mastigophores, the second most abundant cnida (Fig. 1a,c), were most numerous on the distal tentacle. Here medium p-amastigophores were few (Fig. 1a,c), but they were common in the mid-tentacle region. At the tentacle base p-amastigophores outnumbered the medium b-mastigophores (Fig. 1e). Small b-mastigophores (Fig. 1c), small p-amastigophores (Fig. 1d) and isorhizas (Fig. 1c,e) were scattered along the tentacle (Table 1).

Medium p-amastigophores showed a weak positive correlation between increasing anemone size and increasing nematocyst size (regression analysis; $\mathrm{p}<0.043$, $\mathrm{R}-\mathrm{Sq}=0.014)$. The other feeding-tentacle nematocysts showed no such correlation.

\section{Microbasic b-mastigophores, small and medium}

Small and medium b-mastigophores were not always clearly defined and often overlapped when different structures or different specimens were compared. Their capsule width varied. Capsules with a width of $2.5 \mu \mathrm{m}$ or narrower were considered small, even if their length overlapped that of the medium capsules. Capsules with a width of $3.0 \mu \mathrm{m}$ or broader, but with a length of the small size-class, were considered as medium (Table 1).

The tentacle b-mastigophores were identical to small and medium acontia b-mastigophores (Östman et al., 2010a). The pattern of inverted shaft and tubule resembled that of the large mesobasic b-mastigophores, but due to the smaller size of the tentacle nematocysts, the helices on their shaft and the differentiation into proximal and main shaft were not clear (Fig. 1a). On the microbasic, homotrichous shaft up to nine spine-rows were visible (Fig. 1f). The closely-set spines pointed in the direction of eversion. The narrow shaft-tubule gradually tapered into the distal tubule, which was armed with tiny spines and reached $450 \mu \mathrm{m}$ (Fig. 1f).
Micro- and mesobasic p-amastigophores, small and medium

The capsule shape and pattern of inverted shaft, distal tubule and internal capsular matrix (Figs. 1a,c,d, 2e) were similar to those of small and medium acontia p-amastigophores (Östman et al., 2010a).

Micro- and mesobasic p-amastigophores, medium (Table 1). The majority of tentacle p-amastigophores were microbasic, and only a few mesobasic shafts were identified. The distinction between main shaft and proximal shaft was unclear in mature shafts. The central rod-shaped structure was mostly only visible in immature proximal shafts (Fig. 2e,g). The internal capsular matrix formed a U-shaped structure at a distance from the inverted distal shaft (Fig. 1a,c).

Microbasic p-amastigophores, small (Figs. 1d, 2f, Table 1). Only microbasic shafts were identified. The distinction of the main and proximal shaft in mature shafts was faintly visible. The internal capsular matrix was generally squared U-shaped and close to the distal shaft.

\section{Isorhizas and spirocysts}

Isorhizas and spirocysts were not separated into distinct size-classes (Table 1). In the isorhiza capsule the inverted tubule (Fig. 2f) was not always visible (Fig. 1e). The discharged tubule seemed to be spineless and reached up to $60 \mu \mathrm{m}$. In the spirocyst capsule (Fig. 1ad) the inverted tubule was clearly visible through the thin capsular wall. Except for at the capsule base, the coils were regular. The smooth, broad tubule was axially released; the longest was $500 \mu \mathrm{m}$.

\section{Development of feeding-tentacle cnidae}

Cnidoblasts were present along the tentacle in proliferation zones in the lower epidermis beneath mature cnidae (Fig. 2a-d,f,g). In the distal tentacles large zones of cnidoblasts and later stages of developing spirocysts were observed (Fig. 2a-c). The youngest cnidoblasts were spherical (Figs. 2a,b). Some large nuclei and amorphous cell contents were noted (Fig. 2b). In other young cnidoblasts an external tubule was seen outside the folded capsule, especially if the cnidoblast was damaged (Fig. 2a,b,c). Inside large spiroblasts the inverted tubule, forming dense, regular coils perpendicular to the long capsule axis, were clearly visible in folded capsules (Fig. 2a,d). Some developing b-mastigophores and a few p-amastigophores were scattered among the cnidoblasts.

Groups of developing medium b-mastigophores and medium p-amastigophores were abundant in the upper-middle tentacle (Fig. 2e-g). Developing capsules of p-amastigophores were broader than those of b-mastigophores (Fig. 2a,b,g). Their capsules ranged from broad-folded to broad-bow-shaped as the nematocysts matured (Fig. 2c,g). Meanwhile, the shaft and 

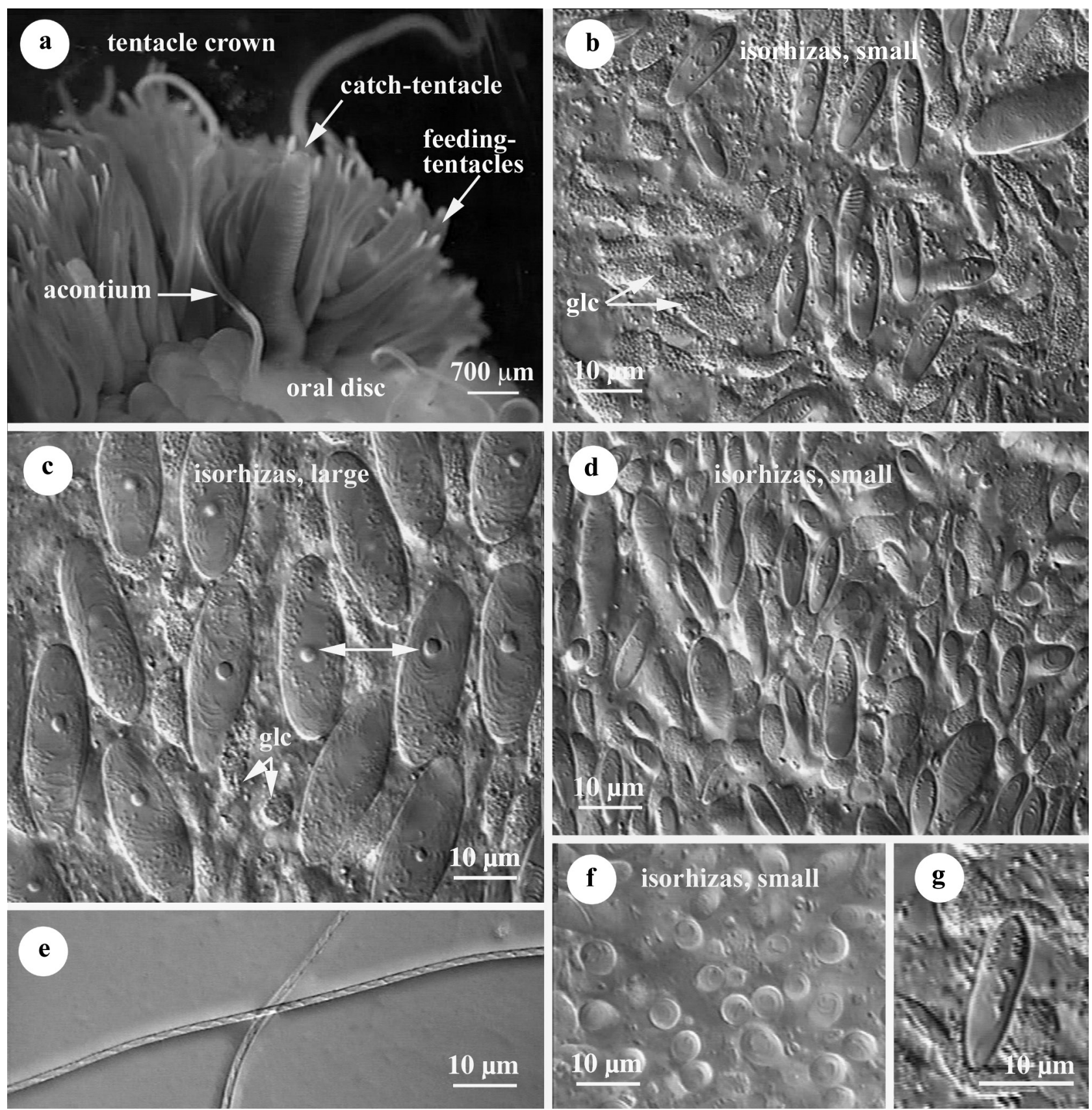

FIG. 3. - Catch-tentacle and catch-tentacle isorhizas. a) Part of tentacle crown with filiform, white tipped feeding-tentacles and one stout contracted catch-tentacle. b-g) Isorhizas from distal catch-tentacle. b) Surface epidermis with small catch-tentacle isorhizas and gland cells (glc). c) Lower epidermis showing large, mature catch-tentacle isorhizas and gland cells (glc). Note small, round structure in centre of mature capsules (double arrow) and the irregularly coiled tubule. d) Lightly squashed preparation showing abundant small isorhizas close together. e) Discharged tubules of large isorhizas showing spine pattern. f) Lightly squashed preparation showing tubule coils in upper capsule of small isorhizas. g) Enlarged small isorhizas showing tubule with regular coils in upper capsule and spares, irregular coils in middle and lower capsule. Double arrow points at small rounded structures; glc, gland cell.

tubule were formed inside the capsule (Fig. 2b,c,g). Gradually the capsules grew straighter and adopted the narrow-elongate shape of mature capsules (Fig. 1a,ce). In developing b-mastigophores the spine pattern was not visible on the narrow, inverted shaft (Fig. 2a). A large nematoblast was sometimes seen connected to a b-mastigophore late in development (Fig. 2b).
As in large acontia p-amastigophores, developing medium p-amastigophores displayed a clear V-shaped spine pattern along the inverted main shaft (Fig. 2f, see Östman et al., 2010a). The V-pattern was indistinct on the flexed proximal shaft with sparse spines (Fig. $2 \mathrm{f}$, prox). The $\mathrm{V}$-shaped notch, shaped by invagination of the shaft end of the p-amastigophores (Fig. 

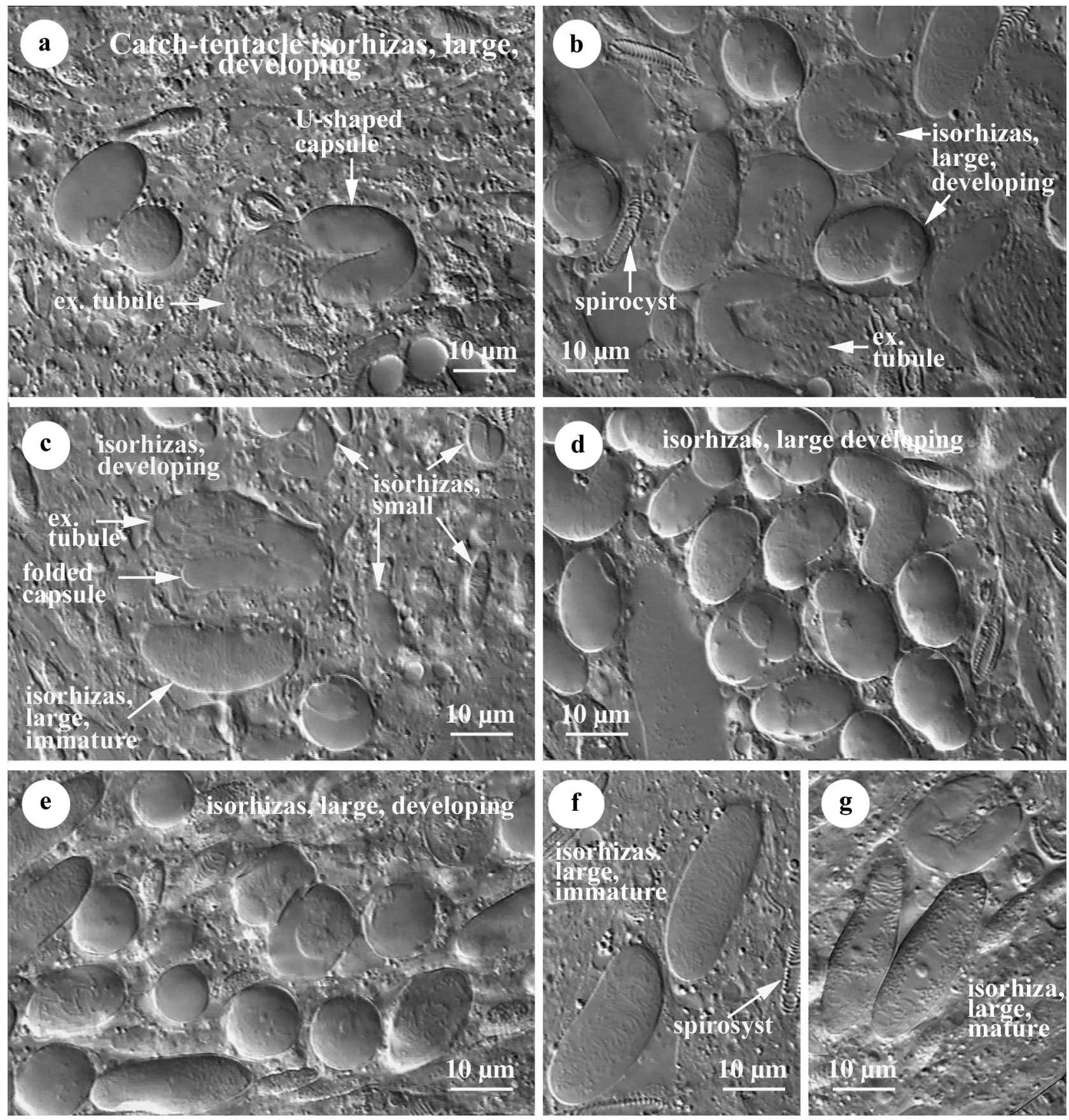

FIG. 4. - Developing catch-tentacle isorhizas from mid-tentacle. a-c) Large isorhizas early in development with folded capsules with external tubule, and round or folded to elongate capsules with inverted, indistinct tubule. Note developing small isorhizas at right in c). d,e) Large, irregular capsules, from round to bow-formed. f) Large isorhizas, late in development, with elongate capsule slightly broader than mature ones, and with indistinct tubule. g) Mature, large isorhizas with small central round structure. Note folded capsule with external tubule in right corner. ex., external.

2f, inv), had not yet been formed, but was noted in pamastigophores later in development (Fig. 2e,g). The $\mathrm{V}$-shaped spine pattern along the main shaft became less distinctive and was gradually replaced by helices as the nematocyst matured (Fig. 2e). As the helices became denser, the shaft grew shorter; the distance between the V-shaped notch and the basal capsule wall increased (Figs. 1a,c,d,e, 2e-g). The helices on the proximal shaft grew especially dense, since spines were sparse here. In mature capsules the proximal shaft shortened the most. The narrow, rod-shaped structure was faintly visible along the centre of the inverted proximal shaft late in development (Fig. 2e, g, see. Östman et al., 2010a,b), but was less visible or invisible in mature p-amastigophores (Figs. 1a,c,d, 2f). In mature p-amastigophores the shaft was straight or nearly so 
(Fig. 1a,c-e). The capsular matrix, forming a characteristic internal structure (Fig. 1a,c,d), was not visible in immature p-amastigophores (Figs. 1d, 2b,e,g) or in discharged capsules.

\section{Catch-tentacles and their cnidae}

In the innermost tentacle cycle of $M$. senile six to seven large, thick, broad-based, blunt-tipped, catchtentacles were present at large distance from each other (Fig. 3a). The opaque, yellow-to-greyish catch-tentacles were easily distinguished from the almost translucent, white-tipped, pointed, slender feeding-tentacles. A slightly contracted catch-tentacle was conical, and its base was 4-5 times broader than an extended catchtentacle and 3-4 times broader than the base of a contracted filiform feeding-tentacle.

Distally on a catch-tentacle two subtypes of isorhizas of different size and with different tubule patterns were abundant in the epidermis (Fig. 3b-g), but the smaller form dominated. The isorhizas were transversely orientated along the tentacle. The small narrow isorhizas were surrounded by numerous large gland cells filled with granules (Fig. 3b). The tubule formed loose, regular coils perpendicular to the long capsule axis, filling the upper narrow capsule (Fig. 3f,g). In the lower capsule the tubule made loose coils towards the base. Spirocysts and common feeding-tentacle nematocysts were typically not present among the small isorhizas.

The larger isorhizas occurred in the epidermis beneath the small isorhizas (Fig. 3c). They were not so numerous or so close together as the small isorhizas but, since they were larger, they were more conspicuous. Their broad, ovate capsule was filled with the irregular, densely coiled tubule. Typically one, sometimes two, small round structures were present close to the centre of what we interpreted as mature capsules (Figs. 3c, $4 \mathrm{~g}$ ). The discharged tubule reached a length of $200 \mu \mathrm{m}$, and helices of the spine-rows were visible along the broad tubule (Fig. 3e).

On the upper mid-tentacle groups of large isorhizas of different ages were scattered among large mature isorhizas (Fig. 4). Only a few small developing isorhizas were identified. Some ordinary feeding-tentacle cnidae, mainly b-mastigophores and p-amastigophores, were noted among the isorhizas. On the lower-mid tentacle, large groups of young nematoblasts of large isorhizas were found. Some capsules were broad and U-shaped and connected to the external tubule (Fig. 4ac), whereas others were straight to irregularly folded. A few small developing isorhizas with U-shaped capsules were observed (Fig. 4c). All common feeding-tentacle cnidae, including spirocysts (Fig. 4b,f), were identified here. Gland cells were scarce (Fig. 4a-f). Toward the tentacle base the common feeding-tentacle cnidae were increasingly numerous. Medium b-mastigophores and spirocysts were the most abundant cnidae here, followed by medium p-amastigophores. Small p-amastig- ophores and ordinary isorhizas were rare (Table 1). No catch-tentacle isorhizas or gland cells were found on the tentacle base.

\section{DISCUSSION}

\section{Tentacle and acontia cnidae}

Feeding-tentacle cnidae were less closely packed, less numerous, and generally smaller than those of the acontia. Only small- and medium-sized cnidae were present on the tentacles (Fig. 1, Table 1); large b-mastigophores and p-amastigophores were absent. Large nematocysts would presumably be more advantageous against predators than small and medium ones (Harris and Duffy, 1980), provided that their venom-potency was similar. In the defensive acontia the adhesive spirocysts and ordinary isorhizas were absent.

Metridium only feeds on small zooplankton (Purcell, 1977a), captured with the feeding-tentacle nematocysts. According to Sebens (1979), the spacing and size of the filtering tentacles were similar in small and large sea anemones. He therefore suggested that tentacle nematocysts which paralysed and caught the prey did not need to increase in size. The tentacles of larger individuals (PPD>30 mm) were, however, larger than those of the smaller sea anemones (PPD $<10 \mathrm{~mm}$ ) and might thus enable larger nematocysts (see Francis, 2004). Medium p-amastigophores showed a modest increase in size with increasing anemone size (our regression analysis; $\mathrm{p}<0.043, \mathrm{R}-\mathrm{Sq}=0.014)$. The increase in size of the defensive, large acontia b-mastigophores and p-amastigophores indicated a slightly larger positive correlation with increasing anemone size $(\mathrm{p}<0.0001$, $\mathrm{R}-\mathrm{Sq}=0.29$ and $\mathrm{p}<0.001, \mathrm{R}-\mathrm{Sq}=0.087$, respectively, Östman et al. (2010a)).

As mentioned above (p. 517), maturation of the tentacle nematocysts, including the differentiation of the inverted shaft of the p-amastigophores (Fig. 2a-c,e$\mathrm{g}$ ), followed the same pattern as described in the large acontial p-amastigophores (Östman et al., 2010a). Identification of young cnidae inside the smallest round cnidoblasts during their capsule- and external tubule-formation was uncertain (Fig. 2a,b). However, we thought that capsule formation, and formation of the external and internal tubule in the spiroblasts, also followed the basic sequence, except for the absence of the shaft (Fig. 2a,b,d).

Due to the small size of feeding-tentacle nematocysts, neither the proximal shaft (with dense helices on the shaft wall) nor the main shaft (with more spaced helices) were as clearly visible as in the acontial large b-mastigophores and p-amastigophores. The helical differentiation of the shaft was only obvious in medium p-amastigophores late in their development (Fig. 2e-g).

The thin rod-shaped structure on the proximal inverted shaft was clearer in immature p-amastigophores (Figs. 1d, 2e,g) than in mature capsules (Fig. 1a,c). The 
rod-shaped structure was also visible in the tentacle amastigophore (= p-amastigophore) of $M$. farcimen (Kramer and Francis, 2004, Fig. 4G). We interpreted this amastigophore as immature because the length of its proximal shaft was proportionally longer than it would be in mature capsules, the position of the Vnotch was close to the capsule end, and no capsular matrix was visible. However, the tentacle amastigophore of M. senile (Kramer and Francis, 2004, Fig. E) was mature. Its shaft—especially the proximal part—was short and the internal matrix was conspicuous.

The size range of b-mastigophores in Swedish $M$. senile was roughly similar to those in $M$. farcimen (as M. fimbriatum) (Carlgren, 1933; Kramer and Francis (2004)), (as M. s. fimbriatum) (Hand, 1956) (Table 1), whereas the p-amastigophores of M. farcimen (same authors') were slightly larger than those of the Swedish M. senile.

\section{Catch-tentacles and their cnidae}

The two different catch-tentacle isorhizas from Swedish and Californian Metridium specimens were similar in capsule shape and in pattern of the inverted tubule (received material from Cadet Hand, see Hand, 1956, p. 197, Fig. 26, ). The larger M. farcimen compared with $M$. senile emphasised the presence of larger nematocysts (Francis, 2004). This might explain the larger maximum size of the large atrichs of $M$. farcimen (as M. s. fimbriatum) noted by Hand (1956) compared with that of the large catch-tentacle isorhizas from the Swedish M. senile (Table 1). The size-range of the smaller catch-tentacle isorhizas was closely similar in the two Metridium populations.

Our squash-preparations were made from living tentacles and not from glutaraldehyde-fixed and sectioned tentacles (Watson and Mariscal, 1983b). The same clear separation between small and large isorhizas in the epidermis, as depicted in H. luciae by Watson and Mariscal (p. 941, Fig. 1), was thus not evident. For the same reason, the division of the tentacle into four regions (Watson and Mariscal 1983b), based upon the maturation gradient of catch-tentacle isorhizas and gland cell distal wards along the tentacle, was not similarly clear in our preparations.

In the distal catch-tentacles, we found some large isorhizas scattered in the upper epidermis among small isorhizas and gland cells (Fig. 3b,d) and in the region beneath, mature large isorhizas (Fig. 3c) were surrounded by some ordinary tentacle-nematocysts.

In the mid-tentacle, as in the material of Watson and Mariscal, developing large isorhizas and some ordinary feeding-tentacle cnidae were surrounding mature large isorhizas. Large isorhizas were considered mature if one or two small round structures were visible in the centre of their capsules (Figs. 3c, 4g).

Regions with large nematoblasts early in development, with capsules of differing shapes and with external tubules or indistinct internal tubule (Fig. 4a-e), were regarded as the lower-tentacle. Large mature isorhizas were rare, but spirocysts and medium b-mastigophores and $\mathrm{p}$-amastigophores were numerous. We are unable to explain why we did not notice a great number of developing small isorhizas (Fig. 4c).

Towards the base of the catch-tentacles of M. senile, ordinary feeding-tentacle cnidae were numerous. The spirocysts in particular seemed to be more abundant here than in H. luciae, reported by Watson and Mariscal (1983b). No early-aged cnidoblasts, as reported in H. luciae, were present on the tentacle base of the Swedish M. senile.

Gland cells, which were abundant in the distal region of the catch-tentacles (Fig. 3b), decreased in number and size towards the tentacle base in $M$. senile (Fig. 4a-f), as reported by Watson and Mariscal (1983b). In our preparations, it was not possible to distinguish the catch-tentacle gland cells from the numerous mucus gland cells in the acontia and in the mesenterial filaments.

\section{ACKNOWLEDGEMENTS}

The study was partly carried out at Kristineberg Marine Research station, Royal Swedish Academy of Science, and at Klubban Biological Station, University of Uppsala, both on the Swedish west coast. We thank the directors and staff for providing laboratory facilities and supplying specimens. The SEM work was performed at the Evolutionary Biology Centre, Uppsala University. Financial support was obtained from Inez Johanssons Stiftelse, Uppsala University. We thank Dr. Elaine Robson, Dr. Paul Cornelius, and the student Grace Wong for their helpful reading of the manuscript and professor Cadet Hand for showing us tentacles with catch-tentacle isorhizas from a Californian Metridium specimen. Special thanks are given to Dr. Daphne Fautin, as referee, for her invaluable assistance with the improvement of our manuscript.

\section{REFERENCES}

Ates, R.M.L. - 1989. Vang- of vechttentacles bij Nederlandse zeeanemonen. Natura, 4: 74-78.

Batham, E. J. and C. F. A. Pantin. - 1951. The organization of muscular system of Metridium senile. Quart. J. Microscop. Sci., 92: 27-54.

Bigger, C.H. - 1988. The role of nematocysts in anthozoan aggression. In: D. A. Hessinger and H. M. Lenhoff (eds.): The Biology of Nematocysts. pp. 295-308. London: Academic Press, San Diego.

Calder, D.R. - 1977. Nematocysts of the ephyra stages of Aurelia, Chrysaora, Cyanea, and Rhopilema (Cnidaria, Scyphozoa). Trans. Amer. Microscop. Soc., 96: 13-19.

Carlgren, O. - 1929. Uber eine Actiniariengattung mit besonderen Fangententaclen. Zool. Anz., 81: 109-113.

Carlgren, O. - 1933. The Godthaab Expedition 1928. Zoantharia and Actiniaria. Meddelelser om Grönland, 79(8): 1-55.

Carlgren, O. - 1945. Further contribution to the knowledge of the cnidome in the Anthozoa especially in the Actiniaria. Acta Univ. Lund (ser 2), 41 (9): 1-24.

Francis, L. - 2004. Microscaling: Why larger anemones have longer cnidae. Biol. Bull., 207: 116-129.

Fukui, Y. - 1986. Catch-tentacle in the sea anemone Haliplanella 
luciae. Roles as organs of social behavior. Mar. Biol., 91: 245-251.

Hand, C. - 1956. The sea anemones of central California part III. The acontiarian anemones. Wasmann J. Biol., 13(2): 189 - 251

Hand, C. - 1961. Present state of nematocyst research: Types, structure and function. In: H. M. Lenhoff and W. F. Loomis (eds.) The Biology of Hydra. pp. 187-202. Univ. Miami Press, Coral Gables, Florida.

Harris, L.G. and S.J. Duffy. - 1980. The influence of prey size on the preference hierarchy of the nudibranch Aeolidia papillosa (L). Am. Zool., 20(4):1087.

Kaplan, S.W. - 1983. Intrasexual aggression in Metridium senile. Biol. Bull., 165: 416-418.

Koehl, M.A.R. - 1976. Mechanical design in sea anemones. In: G.O. Mackie (ed.), Coelenterate Ecology and Behaviour, pp. 23-31. Plenum Press, New York

Kramer, A. and L. Francis - 2004. Predation resistance and nematocyst scaling for Metridium senile and M. farcimen. Biol. Bull., 207: $130-140$

Mariscal, R.N. - 1974. Nematocysts. In: L. Muscatine and H. M. Lenhoff (eds.): The Biology of Nematocysts, Coelenterate Biology, pp. 129-178. Academic Press, New York.

Östman, C. - 1987. New techniques and old problems in hydrozoans systematic. In: J. Bouillon, F. Boero, F. Cigogna and P.F.S Cornelius (eds.), Modern trends in the Systematics, Ecology and Evolution of Hydroids and Hydromedusae, pp. 67-82. Clarendon Press, Oxford.

Östman, C. - 2000. A guideline to nematocyst nomenclature and classification, and some notes on the systematic value of nematocysts. Sci. Mar., 64(sup. 1): 31-46.

Östman, C., W.R. Kem and S. Pirano. - 1991. Nematocysts of the Mediterranean hydroid Halocordyle disticha. Hydrobiologia, 216/217: 607-613

Östman, C., C. Roat, J. Roat Cultima, C. Roat and K. Rundblom. 2010a. Acontia and mesentery nematocysts of the sea anemone Metridium senile (Linnaeus, 1761) (Cnidaria: Anthozoa), Sci. Mar., 74(3): 483-497.

Östman, C., J. Roat Cultima and S.Y.G. Wong. - 2010b. Dart formation in nematocyst of the sea anemone Metridium senile (Linnaeus, 1761) (Cnidaria: Anthozoa), Sci. Mar., 74(3): 499-510.

Purcell, J.E. - 1977a. The diet of large and small individuals of the sea anemone Metridium senile. Bull. S. C. Acad. Sci., 76 $168-172$

Purcell, J.E. - 1977b. Aggressive function and induced development of catch tentacles in the sea anemone Metridium senile
(Coelenterata, Actiniaria) Biol. Bull., 153: 355-368.

Purcell, J.E. and C.L. Kitting. - 1982. Intraspecific aggression and population distributions of the sea anemone Metridium senile. Biol. Bull., 162: 345-349

Sebens, K.P. - 1979. The energetics of asexual reproduction and colony formation in benthic marine invertebrates. Am. Zool., 19: $683-697$.

Sebens, K.P. - 1981. The allometry of feeding, energetics, and body size in three sea anemone species. Biol. Bull., 161: 152-171.

Sebens, K.P. and M.A.R. Koehl. - 1984. Predation on zooplankton by the bentic anthozoans Alcyonium siderium (Alcyonacea) and Metridium senile (Actiniaria) in the New England subtidal. Mar. Biol., 81: 255-271.

Watson, G.M. and R.N. Mariscal. - 1983a. The development of a sea anemone tentacle specialized for aggression: morphogenesis and regression of the catch tentacle of Haliplanella luciae (Cnidaria, Anthozoa). Biol. Bull., 164(3): 506-517.

Watson, G.M. and R.N. Mariscal. - 1983b. Comparative ultrastructure of catch tentacles and feeding tentacles in the sea anemone Haliplanella. Tissue Cell., 15(6): 939-953.

Watson, G.M. and R.N. Mariscal. - 1984a. Calcium cytochemistry of nematocyst development in catch tentacles of the sea anemone Haliplanella luciae (Cnidaria: Anthozoa) and the molecular basis for tube inversion into the capsule. J. Ultrastruct. Res., 86: $202-214$

Watson, G.M. and R.N. Mariscal. - 1984b. Ultrstructure and sulfur cytochemistry of nematocyst development in catch tentacles of the sea anemone Haliplanella luciae (Cnidaria: Anthozoa). J. Ultrastruct. Res., 87: 159-171.

Westfall, J.A. - 1965. Nematocysts of the sea anemone Metridium. Am. Zool., 5: 377-393.

Westfall, J.A. - 1966. The differentiation of nematocysts and associated structures in the Cnidaria. Z. Zellforsh., 75: 381-403.

Williams, R.B. - 1975. Catch-tentacles in sea anemones: occurrence in Haliplanella luciae (Verrill) and a review of current knowledge. J. nat. Hist., 9: 241-248.

Williams, R.B. - 1980. A further note on catch-tentacles in sea anemones. Trans. Norfolk Norwich Nat. Soc., 25: 84-86.

Williams, R.B. - 1991. Acrorhagi, catch tentacles and sweeper tentacles; a synopsis of 'aggression' of actinarian and scleractinian Cnidaria. Hydrobiology, 216/217: 539-545.

Scient. ed.: P.J. López-González.

Received January 13, 2009. Accepted November 11, 2009.

Published online May 14, 2010. 